\title{
A Study of Educational Programmes that Promote Attitude Change and Values Education in Spain
}

\author{
David Pérez-Jorge ${ }^{1}$, Fernando Barragán Medero ${ }^{1} \&$ Elvira Molina-Fernández ${ }^{2}$ \\ ${ }^{1}$ Universidad de La Laguna (ULL), Faculty of Education, Department of Didactics and Educational Research, \\ Tenerife, Spain \\ ${ }^{2}$ Universidad de Granada (UGR), Facultad de Educación y Humanidades, Departamento de Pedagogía, Melilla, \\ Spain
}

Correspondence: David Pérez-Jorge, Faculty of Education, Department of Didactics and Educational Research. Universidad de la Laguna (ULL), Tenerife, Canary Islands, Spain. E-mail: dpjorge@ull.edu.es

Received: April 24, 2017

Accepted: May 30, 2017

Online Published: June 23, 2017

doi:10.5539/ass.v13n7p112

URL: https://doi.org/10.5539/ass.v13n7p112

Project financed by the University of La Laguna and the Ministry of Education of the Government of the Canary Islands

\begin{abstract}
Values education is crucial to promoting the holistic development of students. Many studies over the years have addressed the effects of values education on the holistic development of children, but today there are differing views on how to teach values in school. The objective of this study is to find out more about the programmes that have been used to teach values to children and how they have been developed and applied in schools, and to assess the extent of teachers' knowledge about these programmes. To this end, a bibliometric review was conducted on 161 programmes from 1986 to 2015, complemented by 20 interviews with teachers from different schools. This enabled us to gauge the relevance that has been given to values education over the years, and to assess the need to consider alternative educational models that will enable children to receive a holistic education.
\end{abstract}

Keywords: Attitude change, ethical values, transformative learning, values education

\section{Introduction}

The populations of advanced industrial societies have had to get used to rapid and permanent change, and to the technological, economic and sociopolitical changes that have transformed the culture of societies and their values. It is essential that “(...) 'political education' - the cultivation of the virtues, knowledge, and skills necessary for political participation - has moral primacy over other purposes of public education in a democratic society" (Gutmann, 2001, p.14).

Values are one of the issues that most concern families and educators today, especially in relation to the lack thereof (Carrillo, 2007). Aspects as necessary as solidarity, justice, respect, dialogue and freedom are values that underpin the proper and successful development of society. But what are values? Anything good or bad is a value (Pepper, 1958); the ambiguity and generality of the word may not actually be hiding anything other than its complexity. However, values are guides and determinants of social attitudes and ideologies on one hand and social behaviour on the other (Rokeach, 1973). Whatever the case may be, what seems clear is that a value is no more and no less than the expression of the needs and tendencies of people (Ibañez, 1993).

Values have been studied by many researchers throughout history. They are still today the subject of numerous essays and studies, because of both the complexity of the issues and their continuing relevance. The preventive nature of education and its value as a tool for social change and transformation has led many authors to consider its role to be crucial in improving coexistence and in the creation of a relational model based on respect and acceptance of others (Bajaj (2008), Bajaj \& Chiu (2009), Brenes-Castro (2004), Fermán, Guzmán, Torres, Ahumada \& Díaz (2014), Grasa (2000), Harris \& Morrison (2003), Johnson \& Johnson (2006), Moreno (2015), Muñoz (2014), Rodríguez (2015), Tuvilla (2004), UNESCO (1995). Schools must properly organise the necessary resources, materials and methodology for values education to be a cornerstone of teaching. 
Nevertheless, even today it is difficult to reach consensus on a values education model that is used and accepted by all schools. It may perhaps be of interest to reflect on one of the concepts that is difficult to clarify in relation to this issue. It is difficult to distinguish between values and other related aspects, such as beliefs, attitudes or rules of conduct. In fact, we could say that they are totally different but related concepts, connected by a strong link. We cannot speak of values without reference to our beliefs and our conduct, without considering our attitude to problem solving or the affection that we show in our relationships. This area of personal development and learning gives rise to attitudes that are mediated and influenced by personal experience, by our environment and by society and family culture. Our attitude towards others may manifest greater or lesser solidarity depending on the commitment that the social experience of the subject generates (Pérez-Jorge \& Rodríguez, 2011). Therefore "holistic education should be a basic priority, to ensure that students acquire learning and diverse capacities, other than mere instruction, through experience" (Carreras et al., 2006, p.13). Although this idea may be surprising and although there is reticence to it, it has been and continues to be present in the practices and habits of many teachers. There are a great number of teachers that know how to motivate and to make of their educational practice an experience that is attractive, innovative and experiential. However, these experiences are shared too little and rarely make it beyond the boundaries of the classroom or the school (Pérez-Jorge \& Rodríguez, 2012; Pérez-Jorge, Alegre, Rodríguez-Jiménez, Márquez-Domínguez, \& De la Rosa-Hormiga, 2016).

Seeing educational practice as nothing more than the mere transmission of knowledge through historical events, mathematical or philosophical theories or simple facts is to conform to a situation of limited, incomplete and decontextualised learning. It makes learning a routine, boring experience (Romero, 2014). Education must keep pace with the times, with the facts and events of a world that is increasingly dehumanised and indifferent to what happens around it. Values education is a fundamental part of the social and personal development of the individuals that make up the society in which we live. In the world of today, where violence and a lack of solidarity and ethical behaviour have become commonplace, it is becoming ever more necessary to create spaces for dialogue, thought and reflection in which these values may be developed. It is for this reason that this study was designed: to examine the programmes that are being or have been carried out in the area of education to promote values in students. Gaining better knowledge of values education programmes, and the ways that they are developed and applied in schools, is a crucial step in implementing an appropriate and holistic educational approach.

Schools need to be promoted as learning communities that are capable of involving the educational community in the development of educational projects (Ponce, 2015), with the goal of strengthening pedagogical assumptions that we consider fundamental. Knowing, responding to and engaging with the values of solidarity, tolerance, respect for difference and ideological and cultural diversity are, among others, the key to the effectiveness of these programmes (Romero, 2014; Rodríguez, 2015). They are pedagogical projects that promote solidarity values in children and young persons, that develop their critical thinking and enable them to acquire skills that will equip them to understand the world and engage with the changes that this entails, to endow them with the knowledge and attitudes that will allow them to promote these values and bring about changes in their own lives and in their community, both locally and globally.

The legal provisions that underpin attitude change and values education have given schools the freedom to create the necessary tools to draw up the guidelines for a values education action plan in their Educational Projects (Suárez \& Lorena, 2015). Various units and projects have been designed for schools' annual general programmes (Programación General Anual, PGA) aimed at promoting attitude change and values education. These projects, programmes or didactic units have been developed and applied at different levels in very different ways, and not always with the best results.

The idea behind this study came from the need to analyse the content and actual intentions of the different values education programmes, and the opinions of the teachers.

\section{Objetives}

An effective implementation of values education is essential to achieve the holistic development of students. This aspect of students' education has attracted the interest of many learning programmes that have been designed and developed to achieve this purpose.

The aim of this study is to shed light on the programmes that have been used and are being used in values education, and to find out how they are implemented and applied in schools. To this end, we shall try to provide answers to the following questions:

- What Values Education programmes are being developed and used to promote values education in schools? 
- How are these programmes used and applied in schools?

- What educational dimensions are developed by Values Education programmes?

- Could values be taught differently from how they are taught in schools today?

Based on - and complementing - the above questions, another objective of this study was to determine the extent of teachers' knowledge about values education programmes and their predisposition to use and develop these programmes in educational contexts.

\section{Design and Methodology}

The study that was conducted was eminently qualitative; it was based on the analysis of 161 programmes published between 1986 and 2015 dealing with values education in the area of education. For the analysis of the documents, descriptive or analytical and comparative or synthetic phases were used (Bereday, 1968; Hilker, 1964). These phases enabled us to study and analyse the characteristics of each of the programmes, compare it to the others and draw conclusions (García-Garrido, 1996; Ferrer, 2002).

\subsection{Sample and Procedure}

The study was conducted by reviewing all educational programmes designed for values education that had been implemented in Spanish schools between 1986 and 2015.

A study conducted in 2010 on a total of 102 programmes (Pérez-Jorge, 2010) was used as reference. The programmes included in this study were reviewed and updated up to September 2015, giving us a total of 161 values education programmes. These programmes were designed to be cross-cutting, allowing for intervention from all the different areas of the curriculum (Pérez-Jorge, 2010). Each programme was analysed by four experts in the field of qualitative assessment and with experience in content analysis, who studied the programmes based on the following indicators:

- Identification: author, city and year.

- Content:

- Values and attitudes that were promoted

- Whether they related to problems of social reality

- Their adaptation to the curriculum

- Whether they fostered the holistic development of the student

- Whether they encouraged the participation of the educational community

Twenty complementary interviews with teachers from different schools in the Canary Islands $(\mathrm{N}=20)$ were also conducted. The teachers, who participated voluntarily in the interview, stated that they had worked with values education, had a mean age of 46.5 years and taught in primary $(\mathrm{N}=10)$ and secondary schools $(\mathrm{N}=10)$.

\subsection{Information-gathering Tools and Techniques}

To analyse the values education programmes, a control scale was used to assess the content indicators described above. For these indicators four levels were established, ranging "from a negative, weak and static approach to a positive, dynamic and mobilising conception". These indicators were: "absence of indicator (omitted); level 0 or passive (deterministic view of reality, uncritical acceptance of the facts and stasis); level 1 or informative (purportedly neutral view that presents the facts in a clear and informed way); level 2 or formative (dynamic and interactive view of reality that shows different points of view, favours opinion); and level 3 or transformative (challenges facts, making a critical view of reality and a commitment to change possible)" (Boqué, Pañellas, Alguacil \& García, 2014, p.84).

An interview script was prepared, based on an analysis of the formative dimensions that were developed by the different programmes and their nature. The objective was to ascertain the meaning, use and type of application that these programmes introduced into schools. A content narrative analysis of the answers given by the teachers was conducted, and participants were identified by a "Pn" code (where "P" refers to participant and " $\mathrm{n}$ " the number of the participant).

\section{Results}

\subsection{Analysis of values education programmes 1986-2015}

Once the programmes had been selected, based on the above criteria, they were analysed. It was noted that the programmes had been designed from a disciplinary approach in order to adapt them to different areas of the 
curriculum. These ranged from more specific areas - such as knowledge of values of respect for nature, found in curricula for specific areas - to other more general areas of values education such as peace education, consumer education, equality education, road awareness education, health education, moral and civic education and sex education.

Analysis of the programmes led us to distinguish eight main areas. See Table 1.

Table 1. Areas of the programmes to promote attitude change and values education

\begin{tabular}{|c|c|c|}
\hline Area & $\begin{array}{c}\text { No. of } \\
\text { programmes }\end{array}$ & Values developed \\
\hline $\begin{array}{l}\text { Knowledge of self and of } \\
\text { others }\end{array}$ & 31 & $\begin{array}{l}\text { Self-concept, mutual understanding, group formation, acceptance, } \\
\text { self-esteem }\end{array}$ \\
\hline Discrimination & 22 & Acceptance of others, racism, interculturality, prejudice and solidarity. \\
\hline Conflict & 10 & Collaboration, respect and competitiveness. \\
\hline Interculturality & 9 & Multiculturalism, tolerance and solidarity \\
\hline Human values & 65 & $\begin{array}{l}\text { Attitudes, peace, caring for the environment, critical thinking, cooperation } \\
\text { and value of difference. }\end{array}$ \\
\hline Diversity & 8 & Discrimination, equal opportunities and coexistence, respect for difference. \\
\hline Development cooperation & 8 & Cooperation, conflict, development, human rights and education. \\
\hline Equality & 8 & Co-education, equal rights and dialogue. \\
\hline TOTAL & 161 & \\
\hline
\end{tabular}

In recent years, schools have been considered a place where not only knowledge is taught and know-how transmitted; they are also a place where one learns to live alongside others, to respect others, to be tolerant and above all to be a good citizen. This is perhaps the reality that has increasingly driven the creation of programmes and projects aimed at shaping attitudes and values as the key to the education of the future. Ortega, Mínguez and Gil (1994) argued that values education, together with the development of positive attitudes towards those values, were indispensable components in the educational undertaking. Attitudes and values become the driver of the educational process, giving coherence, and acting as a catalyst, to the component elements of that process. The development of programmes and projects of this kind in schools has favoured critical and humanising interpersonal dialogue and has progressively fostered attitudes of collaboration, making respect for people a vital quality in our relationships with others. In spite of this, values education programmes are not commonly implemented: "I only know of one programme for changing attitudes or for educating in values" (P3), "you educate and teach these aspects of education in your everday work life, when you reprimand a student or when you tell them to apologise to a fellow student whom they have disrespected" (P12). The teachers that participated in this study agreed with values education programmes being implemented, although they saw no way of fitting them in their planning and programming: "the idea of these programmes is fine but I have no time to apply it to my classes" (P18); "I do use some printouts from some of the programmes that I'm familiar with, but not very often, and if I do use them, it's for special days such as the Day of Peace" (P10).

Based on the identified areas, for each programme the following were specified: author, city, publisher and year. To complement this information, the opinions of the teachers about the programmes were also compiled.

\subsubsection{Knowledge of self and of others}

These programmes underscore the importance of knowing one's own feelings and the feelings of others. Their starting point is the fostering of personal values to improve self-concept, self-esteem or self-acceptance. These programmes consider these aspects to be key elements in the holistic development of individuals. See Table 2.

Table 2. Programmes on knowledge of self and of others

\begin{tabular}{llr}
\hline Title & Author, city and publisher & Year \\
\hline Al loro (On the ball) & Lobato, C. and Medina, R. Bilbao: Adarra. & 1986 \\
Pegada de manos (Hand game) & Lobato, C. and Medina, R. Bilbao: Adarra. & 1986 \\
Yo te percibo (I can sense you) & Lobato, C. and Medina, R. Bilbao: Adarra. & 1986 \\
Banco de enfrentar problemas (Problem bank) & Pascual, A. V. Madrid: Narcea. & 1988 \\
$\begin{array}{l}\text { Consecuencias de mis actos (Consequences of } \\
\text { my acts) }\end{array}$ & Pascual, A. V. Madrid: Narcea. & 1988 \\
Tu distintivo (Your badge) & Various. Madrid: Asociación Pro Derechos Humanos. & 1989 \\
\hline
\end{tabular}




Foco (Focus)
¿Sí o no? (Yes or no?)
Teléfono (Telephone)
Árbol familiar (Family tree)
Cómo me ven los demás (How others see me)
Compartir sentimientos (Sharing feelings)
Tarjetas incompletas (Incomplete cards)
Extraterrestres (Extraterrestrials)
Robots
Técnica de la salida (Exit strategy)
Vamos de vacaciones (Let's go on holiday)
Autobiografía (Autobiography)

Bazar mágico (Magic Bazaar)

Escucha activa (Active listening)

Frases incompletas (Incomplete sentences)

Mi futura casa (My future home)

Sherlock Colmes

Escucha activa (Active listening)

Gafas maravillosas (Wonder glasses)

Palabras cruzadas (Crosswords)

Palabras y gestos asesinos (Deadly words and gestures)

Trip, el gusano viajero (Trip the travelling worm)

Educar en la calle (Educating in the street)

Párate a pensar. El valor de la atención (Stop and think. The value of attention)

Párate a pensar. El valor de la atención (Stop and think. The value of attention)
Brunet, J. J. and Negro, J. L. Madrid. San Pío X.

1989

Chauvel, D and Michel, V. Madrid: Narcea.

1989

Chauvel, D and Michel, V. Madrid: Narcea.

1989

Tiedt, P. and Tiedt, I. Boston: Allyn \& Bacon.

1990

Tiedt, P. and Tiedt, I. Boston: Allyn \& Bacon.

1990

Machargo, E. Madrid: Escuela Española

1991

Machargo, E. Madrid: Escuela Española 1991

Jares, J. Madrid: CCS. 1992

Jares, J. Madrid: CCS. 1992

Fritzen, S. J. Santander: Sal Terrae. 1992

Jares, J. Madrid: CCS. 1992

Seminario de Educación para la Paz (Education for Peace 1994 Seminar). Madrid: Catarata.

Seminario de Educación para la Paz. Madrid: Catarata. 1994

Colectivo Armani. Madrid: Popular. 1994

Seminario de Educación para la Paz. Madrid: Catarata. 1994

Seminario de Educación para la Paz. Madrid: Catarata. 1994

Seminario de Educación para la Paz. Madrid: Catarata. 1994

Colectivo Amani. Madrid: Popular. 1994

Colectivo Amani. Madrid: Popular. 1994

Seminario de Educación para la Paz. Valencia: Nau Llibres. 1994

Ortega, P., Mínguez, R. and Gil, R. Valencia: Nau Llibres. 1994

Manos Unidas. Madrid 1995

Manos Unidas. Madrid 2007

Aldeas Infantiles. SOS. España 2014

Aldeas Infantiles. SOS. España 2014

It is curious that the interviewed teachers did not consider the individual dimension to be relevant in promoting values education. Only $10 \%$ of the teachers deemed it relevant, even stating, in one case, that "the important thing in values education is respect for the rules and respect for others" (P2), or, in another, that when choosing a programme for the school "the dimensions that it addresses are not taken into account, rather that it is entertaining and teaches them respect" (P5).

In relation to the indicators of this study, this group of programmes that were designed to develop knowledge of self and of others gave the following results. See Table 3.

Table 3. Development indicators for programmes on knowledge of self and of others

\begin{tabular}{cccccc}
\hline & \multicolumn{3}{c}{ LEVELS } & & \\
\hline INDICATORS & Absent & Passive & Informative & Formative & Transformative \\
\hline \multirow{2}{*}{ Based on problems of social reality } & 0 & 1 & 2 & 16 & 12 \\
Promote values and attitudes & $0 \%$ & $3.2 \%$ & $6.5 \%$ & $51.6 \%$ & $38.7 \%$ \\
& 0 & 2 & 8 & 17 & 4 \\
Adapted to curriculum & $0 \%$ & $6.5 \%$ & $25.8 \%$ & $54.8 \%$ & $12.9 \%$ \\
Favour the holistic development of the & 10 & 14 & 7 & 0 & 0 \\
student & 1 & $45.2 \%$ & $22.6 \%$ & $0 \%$ & $0 \%$ \\
Encourage the participation of the & $3.22 \%$ & $6.5 \%$ & $29.0 \%$ & $54.8 \%$ & 2 \\
educational community & 16 & 4 & 8 & 2 & $6.5 \%$ \\
\hline
\end{tabular}


In the case of the programmes designed to develop knowledge of self and of others, it was observed that these programmes taught social realities from different points of view, inviting students to voice their opinions (51.6\%), that they encouraged the formative development of values and attitudes $(54.8 \%)$, made use of preestablished, rigid curricula (45.2\%) and provided instruction on the importance of holistic development $(54.8 \%)$. With regard to encouraging community participation, $51.6 \%$ did not include the community dimension, compared with $12.9 \%$ who did so in cursory fashion.

\subsubsection{Respect for difference and non-discrimination.}

One of the most important aspects for teachers is undoubtedly respect for difference and non-discrimination. Many of the programmes analysed addressed this aspect, as can be seen in Table 4. From the point of view of the teachers "it is not only about teaching students a particular specialty, but about educating citizens of the future so that they can live with other cultures and in other cities" (P7). Respect for difference is essential for peaceful coexistence, hence "the school has an obligation to encourage it in the classroom, educating in the diversity of the classroom reality" (P10).

Table 4. Projects to promote attitude change and values education: Discrimination

\begin{tabular}{|c|c|c|}
\hline Title & Author, city and publisher & Year \\
\hline Zurdos son diferentes (Lefties are different) & Cratty, B. J. México. Pax & 1986 \\
\hline Análisis de comics (Analysing comics) & Tuvilla, J. Madrid: CCS & 1993 \\
\hline $\begin{array}{l}\text { Candidatos a viaje especial (Candidates for space } \\
\text { travel) }\end{array}$ & Tuvilla, J. Madrid: CCS & 1993 \\
\hline Casos de racismo (Cases of racism) & Tuvilla, J. Madrid: CCS & 1993 \\
\hline La conejita Marcela (Marcela the bunny rabbit) & Tuvilla, J. Madrid: CCS & 1993 \\
\hline Racismo (Racism) & Tuvilla, J. Madrid: CCS & 1993 \\
\hline $\begin{array}{l}\text { Solidaridad frente a racismo (Solidarity against } \\
\text { racism) }\end{array}$ & Martín Sánchez, J. Madrid.: Centro de Profesores Latina. & 1993 \\
\hline Día de la solidaridad (Solidarity Day) & International Cooperation. Madrid & 1993 \\
\hline ¿Puedo entrar? (Can I come in?) & Colectivo Armani. Madrid: Popular. & 1994 \\
\hline $\begin{array}{l}\text { Marginar va contra derechos humanos } \\
\text { (Marginalising goes against human rights) }\end{array}$ & Upper school teaching unit. Bilbao: Justicia y paz. & 1994 \\
\hline Cintas de prejuicios (Tapes of prejudice) & Seminario de Educación para la Paz. Madrid: Catarata. & 1994 \\
\hline ¿Puedo entrar? (Can I come in?) & Colectivo Amani. Madrid: Popular & 1994 \\
\hline Cine contra el racismo (Cinema against racism) & Rodríguez Rojo, M. Barcelona: Oikos-Tau. & 1995 \\
\hline Aprender a convivir (Learning to live together) & Pérez González, M. J. Madrid: Santillana. & 1995 \\
\hline $\begin{array}{l}\text { Nos conocemos, nos apreciamos (We know and } \\
\text { appreciate each other) }\end{array}$ & Carbonel, I. and Davó, M. C. Madrid: Santillana. & 1996 \\
\hline Educar sin barreras (Educate without barriers) & Manos Unidas. Madrid & 2007 \\
\hline Un mundo para cada uno (A world for everyone) & Sorbías, S. Madrid: Narcea. & 1995 \\
\hline Un mundo para cada uno (A world for everyone) & Sorbías, S. Madrid: Narcea. & 1995 \\
\hline $\begin{array}{l}\text { Apadrinamiento entre niños (Sponsorship among } \\
\text { children) }\end{array}$ & Ayuda en Acción & 2013 \\
\hline Ahora toca (Now it's your turn) & Ayuda en Acción & 2013 \\
\hline $\begin{array}{l}\text { Los valores: una experiencia de cine (Values: a } \\
\text { cinema experience) }\end{array}$ & BNP. Paribas. Madrid. & 2013 \\
\hline $\begin{array}{l}\text { Aulas del siglo XXI. Innovación educativa. Grupos } \\
\text { cooperativos. Tics, tareas y proyectos. ( } 21 \mathrm{st} \text { century } \\
\text { classrooms. Educational innovation. Cooperative } \\
\text { groups. ICTs, tasks and projects.) }\end{array}$ & FAD Teacher Action Prize. Madrid. & 2014 \\
\hline
\end{tabular}

As Arnaiz (2012) contended, it is possible to educate and prevent discrimination in the classroom by discussing discriminatory situations, trying to show students the value of difference and instilling respect for gender, race or religion, etc. 
In relation to the indicators of this study, this group of programmes that were designed to teach respect for difference and non-discrimination gave the following results. See Table 5.

Table 5. Development indicators for programmes on respect for difference and non-discrimination

\begin{tabular}{|c|c|c|c|c|c|}
\hline \multicolumn{6}{|c|}{ LEVEL } \\
\hline INDICATORS & Absent & Passive & Informative & Formative & Transformative \\
\hline \multirow{2}{*}{ Based on problems of social reality } & 0 & 1 & 3 & 14 & 4 \\
\hline & $0 \%$ & $4.5 \%$ & $13.6 \%$ & $63.6 \%$ & $27.3 \%$ \\
\hline \multirow{2}{*}{ Promote values and attitudes } & 0 & 2 & 2 & 14 & 4 \\
\hline & $0 \%$ & $9.1 \%$ & $9.1 \%$ & $63.6 \%$ & $18.9 \%$ \\
\hline \multirow{2}{*}{ Adapted to curriculum } & 7 & 14 & 1 & 0 & 0 \\
\hline & $33.3 \%$ & $63.6 \%$ & $4.8 \%$ & $0 \%$ & $0 \%$ \\
\hline \multirow{2}{*}{ Favour the holistic development of the student } & 1 & 2 & 2 & 17 & 0 \\
\hline & $4.5 \%$ & $9.0 \%$ & $9.0 \%$ & $77.2 \%$ & $0 \%$ \\
\hline \multirow{2}{*}{$\begin{array}{l}\text { Encourage the participation of the educational } \\
\text { community }\end{array}$} & 15 & 3 & 2 & 1 & 1 \\
\hline & $68.2 \%$ & $13.6 \%$ & $9.1 \%$ & $4.5 \%$ & $4.5 \%$ \\
\hline
\end{tabular}

In the case of the programmes designed to address discrimination, it was observed that these programmes were based on social realities in order to make them known and to create a climate of opinion among students (63.6\%), that they encouraged the formative development of values and attitudes (63.6\%), made use of preestablished, rigid curricula (63.6\%), and taught with a view to the holistic development of the students $(63.6 \%)$. With regard to encouraging community participation, $68.2 \%$ did not include the community dimension.

\subsubsection{Interculturality}

The development of these programmes arose from two basic premises (Romero, 2014): the right of all children to a quality education and the importance of taking into account the cultural diversity that characterises us all. See Table 6.

Table 6. Projects to promote attitude changes and values education: Interculturality

\begin{tabular}{|l|l|l|}
\hline Title & Author, city and publisher & Year \\
\hline Solidaridad (Solidarity) & Palos, J. et al. Barcelona: Intermón-Octaedro. & 1995 \\
\hline $\begin{array}{l}\text { Los cuatro viajeros en el Aquarium (The four travellers in the } \\
\text { aquarium) }\end{array}$ & Asha Miró & 2003 \\
\hline Hagamos un poco de historia (Let's make some history) & Sodepan. Madrid. Catarata. & 2003 \\
\hline Acerquémonos a... (Let's get closer to...) & Sodepan. Madrid. Catarata. & 2003 \\
\hline $\begin{array}{l}\text { Una cultura más próxima de lo que pensamos (A closer } \\
\text { culture than we think) }\end{array}$ & Sodepan. Madrid. Catarata. & 2004 \\
\hline Yahora, ¿qué? (And now what?) & Sodepan. Madrid. Catarata. & 2004 \\
\hline Palabras con sentido (Meaningful words) & Vega, F. Cano, J. P. Madrid. & 2004 \\
\hline Educar para la reinserción (Educating for reintegration) & Manos Unidas. Madrid & 2007 \\
\hline “La ciudad soñada” Educ-Arte (“The dream city” Educ-Arte) & Fundación Yehudi Menuhin España & 2014 \\
\hline
\end{tabular}

From the analysis of these programmes it was observed that they began by defining the concepts of culture (focusing on the field of education) and interculturality, the latter referring to interaction, negotiation and enrichment between different cultures. Moreover, the multiculturalism approach alluded to the existence of diverse cultures (multicultural contexts), but without the communication process focused on identifying that multiculturalism without delving any further and without arousing an interest in sharing and enriching other cultures. One teacher affirmed that "the important thing was to know other cultures and that is why it is important to travel" (P3).

In relation to this dimension we consider that:

(...) the role of the school should be to address cultural differences in order to work coherently on equal rights and social participation, because this ensures the success of essential educational objectives, i.e. construction of identity and equal opportunities. To achieve this goal it is important to become aware that education, if not intercultural, is not an education. It is necessary to adopt a position in which interculturality is a model and in 
which difference is the norm, promoting exchanges between groups so that, in this way, it becomes possible to create spaces where interconnections are established (Repetto \& Carvalho, 2015, p. 60).

The indicators of this study for the group of programmes that were designed to tackle interculturality gave the following results. See Table 7.

Table 7. Development indicators for programmes on interculturality

\begin{tabular}{|c|c|c|c|c|c|}
\hline \multicolumn{6}{|c|}{ LEVELS } \\
\hline INDICATORS & Absent & Passive & Informative & Formative & Transformative \\
\hline \multirow[t]{2}{*}{ Based on problems of social reality } & 0 & 0 & 3 & 6 & 0 \\
\hline & $0 \%$ & $0 \%$ & $33.3 \%$ & $66.7 \%$ & $0 \%$ \\
\hline \multirow[t]{2}{*}{ Promote values and attitudes } & 0 & 0 & 1 & 7 & 1 \\
\hline & $0 \%$ & $0 \%$ & $11.1 \%$ & $77.8 \%$ & $11.1 \%$ \\
\hline \multirow[t]{2}{*}{ Adapted to curriculum } & 2 & 4 & 2 & 1 & 0 \\
\hline & $22.2 \%$ & $44.4 \%$ & $22.2 \%$ & $11.1 \%$ & $0 \%$ \\
\hline \multirow{2}{*}{$\begin{array}{l}\text { Favour the holistic development of } \\
\text { the student }\end{array}$} & 1 & 2 & 1 & 5 & 0 \\
\hline & $11.1 \%$ & $22.2 \%$ & $11.1 \%$ & $55.5 \%$ & $0 \%$ \\
\hline \multirow{2}{*}{$\begin{array}{l}\text { Encourage the participation of the } \\
\text { educational community }\end{array}$} & 6 & 2 & 1 & 0 & 0 \\
\hline & $66.7 \%$ & $22.2 \%$ & $11.1 \%$ & $0 \%$ & $0 \%$ \\
\hline
\end{tabular}

In the case of the programmes designed to address this area, it was observed that these programmes were based on social realities with the aim of generating opinions and points of view that were different from those realities (66.7\%), that they encouraged the formative development of values and attitudes (77.8\%), that they did not include content that was sufficiently adapted to school curricula (22.2\%) or simply made use of preestablished, rigid curricula (44.4\%), and that they taught with a view to the holistic development of the students (55.5\%). With regard to encouraging community participation, $66.7 \%$ did not encourage the community dimension.

\subsubsection{Conflict}

Coexistence is one of the most important aspects of human relationships. Disagreements, disputes and situations can arise as a natural manifestation of these relationships, potentially leading to interpersonal conflict. For this reason, we believe that coexistence and conflict occupy the same stage. But we cannot ignore that we live in a society where conflicts are sometimes resolved violently and, although violent situations appear in isolation, we cannot deny that they exist. The role of prevention as a tool for improving coexistence is essential for achieving a suitable climate for relationships. See Table 8.

Table 8. Projects to promote attitude change and values education: Conflict

\begin{tabular}{llc}
\hline Title & Author, city and publisher & Year \\
\hline Aguantar el muro (Enduring the wall) & Seminario de Educación para la Paz. Madrid: Catarata. & 1994 \\
Consejo escolar (School council) & Seminario de Educación para la Paz. Madrid: Catarata. & 1994 \\
Fumadores (Smokers) & Seminario de Educación para la Paz. Madrid: Catarata. & 1994 \\
Paz (Peace) & Tuvilla, J. Madrid: CCS & 1993 \\
Pelea en la escuela (Conflict at school) & Hicks, D. Madrid: MEC- Morata. & 1993 \\
Tarjetas de conflictos (Conflict cards) & Tuvilla, J. Madrid: CCS & 1993 \\
Collage en competición (Collage competition) & Seminario de Educación para la Paz. Madrid: Catarata. & 1994 \\
Palabras cruzadas (Crosswords) & Seminario de Educación para la Paz. Valencia: Nau Llibres. & 1994 \\
Jornada de Katy (Katy's day) & Hicks, D. Madrid: MEC- Morata. & 1993 \\
\hline
\end{tabular}

In relation to this area, one interviewee (P8) said "I'm tired of punishing them when they fight, punishment does not in itself prevent the appearance of conflict, so the children show aggressive behaviour toward their peers again and again". It is necessary to provide children with tools and resources for positive and successful interaction that prevents the appearance of conflict (Pérez-Jorge, 2010b).

The indicators of this study for the group of programmes that were designed to tackle conflict gave the following results. See Table 9. 
Table 9. Development indicators for programmes on conflict

\begin{tabular}{cccccc}
\hline & \multicolumn{3}{c}{ LEVELS } & & \\
\hline INDICATORS & Absent & Passive & Informative & Formative & Transformative \\
\hline Based on problems of social reality & 1 & 1 & 0 & 6 & 0 \\
Promote values and attitudes & $10.0 \%$ & $10.0 \%$ & $0 \%$ & $60.0 \%$ & $0 \%$ \\
Adapted to curriculum & 0 & 0 & 3 & 6 & 1 \\
Favour the holistic development of & $0 \%$ & $\%$ & $30.0 \%$ & $60.0 \%$ & $10.0 \%$ \\
the student & 0 & 7 & 2 & 1 & 0 \\
Encourage the participation of the & $10 \%$ & $70.0 \%$ & $20.0 \%$ & $10.0 \%$ & $0 \%$ \\
educational community & $60.0 \%$ & $10.0 \%$ & $0 \%$ & $80.0 \%$ & 0 \\
\end{tabular}

In the case of the programmes designed to address conflict, it was observed that they were programmes based on dissimilar social realities with the aim of generating different opinions and views $(60.0 \%)$, that they encouraged the formative development of values and attitudes $(60.0 \%)$, that, informatively, they included the curriculum areas from which educational intervention should be addressed (70.0\%) and that they taught with a view to the holistic development of the students $(80.0 \%)$. With regard to encouraging community participation, $60.0 \%$ did not include the community dimension.

\subsubsection{Values Education}

A quality education should look more to quality in terms of human values than the quality of instruction. In today's global society, personal relationships and what is now termed social competence are key to improving the quality of relationships between people and, especially, between children. This social dimension establishes a significant part of the educational goals that lie on the social horizon of a democratic state governed by the rule of law. To teach values is to teach solidarity and freedom. The substrate that sustains the basic pillars of education is ethical. Hence:

(...) each individual educates himself or herself, discovering values with their own experiential freedom in the family, at school, in the street, on television and other media. The people most meaningful to the child or young person are those who have the greatest influence on their experience of values: parents, teachers, educators, tutors... And once internalised, values become guiding principles that map out guidelines for coherent behaviour. They become ideals that indicate the way forward. (Martín, 2011, p.127).

Thus, these programmes focused on teaching children the meaning of their actions, on making the right decisions, on taking responsibility for their own actions and accepting the consequences.

Many of the teachers indicated that education primarily "has to teach children to be people" (P12), to "live in harmony and respect" (P16), to "be critical in order to know how to make a decision" (P17), to "learn to appraise oneself and others" (P11), being sure "always to promote equality and respect for the other and for others" (P19).

The variety of programmes found in relation to this area made it clear that it is one of the prevalent areas considered when designing intervention plans. See Table 10.

Table 10. Projects to promote attitude change and values education: Values Education

\begin{tabular}{|c|c|c|}
\hline Title & Author, city and publisher & Year \\
\hline Análisis de valores (Analysis of values) & Puig, J. M. and Martínez, M. Barcelona: Laertes. & 1989 \\
\hline Simulación (Simulation) & Puig, J. M. and Martínez, M. Barcelona: Laertes. & 1989 \\
\hline Corro de la tarde (Group circle in the afternoon) & $\begin{array}{l}\text { Seminario de Educación para la Paz. Madrid: } \\
\text { Catarata. }\end{array}$ & 1994 \\
\hline Nudos de manos entrelazadas (Hand clasping) & Pulet, R. Archidona: Aljibe. & 1995 \\
\hline Habilidades socials (Social skills) & Puig, J. M. Barcelona: ICE-Horsori. & 1995 \\
\hline Modelado (Modelling) & $\begin{array}{l}\text { Puig, J. M. and Martínez, M. Barcelona: } \\
\text { ICE-Horsori. }\end{array}$ & 1995 \\
\hline Hacer para aprender (Do to learn) & International Cooperation. Madrid. & 1998 \\
\hline $\begin{array}{l}\text { Deuda externa. ¿Deuda externa? (External debt. External } \\
\text { debt?) }\end{array}$ & Manos Unidas. Madrid & 2001 \\
\hline Los rostros de la violencia (The faces of violence) & Manos Unidas. Madrid & 2001 \\
\hline
\end{tabular}


Religiones; aprender a caminar en paz (Religions; learn to
walk in peace)
Razones para la guerra, razones para la paz (Reasons for
war, reasons for peace)
El señor de los mosquitos; La comunidad de las moscas
(The lord of the mosquitoes; the fellowship of flies)
El desarrollo, camino para la Paz (Development, the path
to Peace)
Ojos que sí ven (Eyes that see)
El señor de los mosquitos; Los dos taros (The lord of the
mosquitoes; the two jars)
Globalicemos la solidaridad (Let's globalise solidarity)

El señor de los mosquitos; El retorno de la ley. (The lord of the mosquitoes; the return of the law.)

Norte-Sur; un futuro común (North-South; a shared future)

El derecho a la alimentación (The right to food)

Cuidadores de toda la creación (Carers of all creation)

Sabes leer, ellos no. Podemos cambiarlo (You can read, they cannot. We can change that)

Educar para la Paz (Educating for Peace)

Educar en la discapacidad (Educating about disability)

Educación sin discriminación (Education without discrimination)

Vidas minadas, diez años después (Mined lives, ten years later)

Educación para las minorías (Education for minorities)

Lograr la educación primaria universal (Achieving universal primary education)

Madres sanas, derechos y esperanzas (Healthy mothers, rights and hopes)

Sumando valores: bondad + diálogo $=P a z$ (Adding values: kindness + dialog $=$ Peace)

Me gustaría saber más sobre residuos (I want to know more about waste)

Yo colaboro con el medio ambiente (I help with the environment)

El valor de reflexionar, de colaborar y de compartir (The value of reflecting, collaborating and sharing)

Seamos sostenibles (Let's be sustainable)

El $4^{\circ}$ Hocico (The 4th Snout)

La paciencia, la escucha y la sostenibilidad (Patience, listening and sustainability)

El valor de la autonomía, la amabilidad y la libertad (The value of autonomy, kindness and freedom)

Abraza tus valores, autonomía, amabilidad y libertad (Embrace your values, autonomy, kindness and freedom)

Abraza tus valores. El valor de la familia (Embrace your values. The value of family)

Abraza tus valores. El valor de la atención (Embrace your values. The value of attention)

"Formación profesorado (CEIP): Escuelas creativas, espacios saludables. "Cine y Valores: Proyecta tu futuro" ("Teacher Training (CEIP): Creative schools, healthy spaces. "Cinema and values: project your future")

Menudo Dilema (What a dilemma)

El banco del tiempo del principito (The Little Prince's time bank)

El trébol de la paz: cuido de mi mismo, cuido de los demás, cuido de lo que me rodea. (Peace clover: I care for myself, I care for others, I care for my surroundings.)

Proyecto solidario Telopido ("Telopido" charity project)
Manos Unidas. Madrid

2002

Manos Unidas. Madrid

2002

Manos Unidas

2003

Manos Unidas. Madrid

2003

Willians Ramos, J. Madrid.

2004

Manos Unidas. Madrid

2004

Manos Unidas. Madrid 2004

Manos Unidas. Madrid 2005

Manos Unidas. Madrid 2005

Manos Unidas. Madrid 2005

Manos Unidas. Madrid 2006

Manos Unidas. Madrid 2007

Manos Unidas. Madrid 2007

Manos Unidas. Madrid 2007

Manos Unidas. Madrid 2007

Manos Unidas. Madrid 2007

Manos Unidas. Madrid 2007

Manos Unidas. Madrid 2008

Manos Unidas. Madrid 2008

Aldeas Infantiles. SOS. España 2009

Aldeas Infantiles. SOS. España 2009

Aldeas Infantiles. SOS. España 2010

Aldeas Infantiles. SOS. España 2010

Aldeas Infantiles. SOS. España 2011

Bona, García, C. ed. Atagón. 2011

Aldeas Infantiles. SOS. España 2011

Aldeas Infantiles. SOS. España 2012

Aldeas Infantiles. SOS. España 2012

Aldeas Infantiles. SOS. España 2013

Aldeas Infantiles. SOS. España 2014

Santa Cruz de Tenerife Town Council 2013

Aldeas Infantiles. SOS. España 2014

FAD Teacher Action Prize. Madrid. 2014

FAD Teacher Action Prize Special Mention. 2014 Madrid.

FAD Special Mention "families". Madrid. 
Mamá, papá acompáñame a aprender (Mum, Dad, come learn with me)

Nosotros contamos. Una experiencia de escuela inclusiva. (We count. An inclusive school experience.)

Valores de futuro BBVA (BBVA future values)

E2 $=$ Educación + Energía $(\mathrm{E} 2=$ Education + Energy $)$

Red canaria de escuelas promotoras de salud (RCEPS)

(Canary Islands network of health promoting schools)

Párate a pensar. El valor de la familia (Stop and think. The value of family)

"Necesidades, Derechos y Cooperación al Desarrollo de la Infancia" ("Needs, Rights and Development Cooperation for Children")

Máster Universitario en Cooperación Internacional Descentralizada: Paz y Desarrollo (Master in Decentralised International Cooperation: Peace and Development)

"Proyecto MUS-E" ("MUS-E Project")

AMALGAMA: Programa de educación en Valores $y$ profesorado de $1^{o}$ de ESO (AMALGAMA: values education programme 1st yr secondary school)

"Educar en familia" ("Educating in the family")

"Escuelas por un Desarrollo Sostenible" ("Schools for Sustainable Development")

"Educar la Paz, la solidaridad y los Derechos Humanos" ("Educating Peace, Solidarity and Human Rights")

"Juguemos a ser una asociación" ("Let's play at being an association")

PartiSipación (Participation, yes.)

Red canaria de centros educativos para la sostenibilidad (Canary Islands network of schools for sustainability)

Personas + Sostenibles. Islas ecológicas didácticas (+ Sustainable People. Didactic eco-islands)

"La jornada solidaria del CEIP Gran Canaria. Un proyecto de escuela y familia" ("CEIP Day of solidarity Gran Canaria. A project for school and family")

Abraza tus valores. El valor de la familia (Embrace your values. The value of family)

Abraza tus valores. El valor de la atención (Embrace your values. The value of attention)
FAD Teacher Special Mention. Madrid.

2014

FAD Teacher Special Mention. Madrid.

Fundación BBVA. Madrid.

2014

Fundación Repsol and National Library of Spain 2014

Canary Islands Government

2014

Aldeas Infantiles. SOS. España

2015

UAM and UNICEF España

UNICEF País Vasco

Fundación Yehudi Menuhin España

2014

Equality service of Department for youth, sports,

road education and safety, Lanzarote Island Council

Santa Cruz de Tenerife City Council, 2015

Autonomous Sports Bodies.

Santa Cruz de Tenerife City Council, Fundación 2014

Santa Cruz Sostenible and Fundación DISA

Canary Islands Association of Teachers for Peace 2012

and Solidarity

Youth Department, Los Realejos Town Council 2010

Youth Department, Los Realejos Town Council 2013

Canary Islands Government 2014

Tenerife Island Council. Canary Islands 2013

Government

Educational community

Aldeas Infantiles. SOS. España

Aldeas Infantiles. SOS. España

2014

The indicators of this study for the group of programmes that were designed to tackle the development of human values gave the following results. See Table 11

Table 11. Development indicators for programmes on human values

\begin{tabular}{|c|c|c|c|c|c|}
\hline \multicolumn{6}{|c|}{ LEVELS } \\
\hline INDICATORS & Absent & Passive & Informative & Formative & Transformative \\
\hline Based on problems of social & 6 & 10 & 7 & 37 & 5 \\
\hline reality & $9.3 \%$ & $15.4 \%$ & $22.6 \%$ & $56.9 \%$ & $7.7 \%$ \\
\hline \multirow{2}{*}{ Promote values and attitudes } & 0 & 2 & 18 & 42 & 3 \\
\hline & $0 \%$ & $3.1 \%$ & 27.7 & $64.6 \%$ & $4.6 \%$ \\
\hline \multirow{2}{*}{ Adapted to curriculum } & 17 & 39 & 6 & 3 & 0 \\
\hline & & $60.0 \%$ & $9.2 \%$ & $4.6 \%$ & $0 \%$ \\
\hline Favour the holistic & 7 & 5 & 12 & 39 & 2 \\
\hline development of the student & $10.8 \%$ & $7.7 \%$ & $18.5 \%$ & $60.0 \%$ & $3.1 \%$ \\
\hline Encourage the participation of & 42 & 10 & 9 & 3 & 1 \\
\hline the educational community & $64.6 \%$ & $15.4 \%$ & $13.8 \%$ & $4.6 \%$ & $1.5 \%$ \\
\hline
\end{tabular}


In the case of the programmes designed to address human values, it was observed that these programmes were based on social realities with the aim of generating different opinions and points of view $(56.9 \%)$, that they encouraged the formative development of values and attitudes $(64.6 \%)$ and that they did not make use of contents that were sufficiently adapted to school curricula (26.2\%) or simply made use of them in an ambiguous or non-specific way $(60,0 \%)$, and that they taught with a view to the holistic development of the students $(60.0 \%)$. With regard to encouraging community participation, $64.6 \%$ did not address the community dimension.

\subsubsection{Diversity}

Melero (2001) \& González (2015) contended that when teachers hear about diversity today, many think about persons with disabilities and students from other cultures and religions. Difference has become synonymous with "other", it is "what is missing from this for it to become that", a "deficiency, disability or abnormality" that makes one not efficient, valid or normal.

It is an undeniable fact that the value of diversity, and the potential that diversity brings to the teaching-learning process, has been given due recognition. This has been possible thanks to the basic principles of respect for student heterogeneity that have permeated schools in their desire to respond more adequately to their students. The framework of this reality - called inclusive education (Ainscow, Beresford, Harris, Hopkins \& West, 2001; Gross, 2004; Gispert, 2008; Echeita, 2009 \& Kechikian, 2015) - has led to the emergence of effective schools (Arnániz, 2011), for which the core idea is that, since all children learn differently, schools have to develop models that are responsive to their needs. Accordingly, as proposed by Pérez-Jorge (2010b) \& Arnaniz (2012), a change is necessary in teaching-learning organisation and strategies in order to promote equality and equity for all children. See Table 12.

Table 12. Projects to promote attitude change and values education: Diversity

\begin{tabular}{|c|c|c|c|}
\hline Title & Values developed & Author, city and publisher & Year \\
\hline $\begin{array}{c}\text { Equipo de clase con gitanos } \\
\text { (Class team with Roma } \\
\text { children) }\end{array}$ & $\begin{array}{c}\text { Values clarification, } \\
\text { Discrimination, Intercultural. }\end{array}$ & $\begin{array}{l}\text { Buxarrais, M. R: et el. Barcelona: rosa } \\
\text { Sensat. }\end{array}$ & 1990 \\
\hline $\begin{array}{c}\text { Frases incompletas (Incomplete } \\
\text { sentences) }\end{array}$ & $\begin{array}{l}\text { Values clarification, } \\
\text { Discrimination, Intercultural. }\end{array}$ & $\begin{array}{c}\text { Buscarais, M. R. et al. Barcelona: Rosa } \\
\text { Sensat. }\end{array}$ & 1990 \\
\hline $\begin{array}{l}\text { Educar en la Universidad } \\
\text { (Educating at University) }\end{array}$ & $\begin{array}{l}\text { Diversity and equal } \\
\text { opportunities. }\end{array}$ & Manos Unidas. Madrid & 2007 \\
\hline $\begin{array}{l}\text { Educación para los adultos } \\
\text { (Adult Education) }\end{array}$ & Diversity and education & Manos Unidas. Madrid & 2007 \\
\hline $\begin{array}{c}\text { Educar en la calle (Educating } \\
\text { in the street) }\end{array}$ & Acceptance and support & Manos Unidas. Madrid & 2007 \\
\hline $\begin{array}{c}\text { Juntos podemos (Together we } \\
\text { can) }\end{array}$ & $\begin{array}{l}\text { Social inclusion through } \\
\text { promotion of values }\end{array}$ & FAD Teacher Special Mention. Madrid. & 2014 \\
\hline Enamóra $+E$ (Fall in love) & $\begin{array}{l}\text { Educating for solidarity through } \\
\text { learning }\end{array}$ & $\begin{array}{l}\text { Charity project of the Ceuta educational } \\
\text { community and Red Cross Spain }\end{array}$ & 2014 \\
\hline $\begin{array}{c}\text { Programa de intervención } \\
\text { educativa FELGTB (FELGTB } \\
\text { Educational intervention } \\
\text { programme) }\end{array}$ & $\begin{array}{l}\text { Fostering diversity, equal } \\
\text { opportunities, peace, } \\
\text { coexistence in the classroom } \\
\text { and values education }\end{array}$ & $\begin{array}{c}\text { ALGARABIA (Tenerife) and ALTIHAY } \\
\text { (Fuerteventura) }\end{array}$ & 2014 \\
\hline
\end{tabular}

In the words of the teachers, "education in the area of diversity is essential" (P12) and they argued that "coexistence within diversity offers opportunities for both students who are from a diverse background and those who are not" (P14). They felt that the context of "a diverse school is the context closest to the reality that students will face when they enter society" (P8) and therefore it "is that which gives the best guarantees for achieving true inclusion in school and society" (P6).

The indicators of this study for the group of programmes that were designed to tackle diversity gave the following results. See Table 13 .

Table 13. Development indicators for programmes on diversity

\begin{tabular}{cccccc}
\hline & LEVELS & & & \\
\hline INDICATORS & Absent & Passive & Informative & Formative & Transformative \\
\hline & 1 & 1 & 2 & 4 & 0 \\
Based on problems of social reality & $12.5 \%$ & $12.5 \%$ & $25.0 \%$ & $50.0 \%$ & $0 \%$ \\
Promote values and attitudes & 0 & 1 & 3 & 4 & 0 \\
\hline
\end{tabular}


Adapted to curriculum

Favour the holistic development of the student

Encourage the participation of the educational community

$\begin{array}{ccccc}2 & 5 & 1 & 0 & 0 \\ 25.0 \% & 62.5 \% & 12.5 \% & 0 \% & 0 \% \\ 0 & 0 & 2 & 6 & 0 \\ 0 \% & 0 \% & 25.0 \% & 75.0 \% & 0 \% \\ 5 & 2 & 1 & 0 & 0 \\ 62.5 \% & 25.0 \% & 12.5 \% & 0 \% & 0 \%\end{array}$

In the case of the programmes designed to address diversity, it was observed that these programmes were based on social realities with the aim of informing and educating about the reality of diversity $(75.0 \%)$, that they encouraged the formative development of values and attitudes $(50.0 \%)$, that their contents were not sufficiently adapted to school curricula $(62.5 \%)$, and that they taught with a view to the holistic development of the students $(75.0 \%)$. With regard to encouraging community participation, $62.5 \%$ did not explicitly include the community dimension.

\subsubsection{Development cooperation}

One of the objectives of education is to create citizens who are committed to peace, respect for human rights, community life, social cohesion, cooperation and solidarity amongst peoples. It also aspires to enable them to acquire values conducive to respect for living beings and the environment, in particular, understanding the value of forest areas and sustainable development.

Mendoza, Romero \& Wetshokonda (2015) believe that there is an inextricable link between education and development, since both reflect the moral character of humans. In education, any action is imbued with a conception of the person, and from this, certain values are promoted that affect the environment. Therefore any action that has a bearing on the environment will be mediated from the plane of acquired values, affecting or promoting changes and improvements. See Table 14 for the programmes developed in this area of intervention.

Table 14. Projects to promote attitude change and values education: Development Cooperation

\begin{tabular}{|c|c|c|c|}
\hline Title & Values developed & Author, city and publisher & Year \\
\hline Isla desierta (Desert island) & Cooperation, conflict & $\begin{array}{c}\text { Seminario de Educación para la } \\
\text { Paz. Madrid: Catarata. }\end{array}$ & 1994 \\
\hline Labradores (Labourers) & $\begin{array}{l}\text { Development, } \\
\text { conflict }\end{array}$ & $\begin{array}{c}\text { Seminario de Educación para la } \\
\text { Paz. Madrid: Catarata. }\end{array}$ & 1994 \\
\hline Historia de burros (History of donkeys) & $\begin{array}{l}\text { Cooperation and } \\
\text { conflict. }\end{array}$ & Linares, J. Orihuela: C.E.P. & 1993 \\
\hline Programa Sersak (Sersak programme) & Human rights & $\begin{array}{c}\text { International Cooperation. } \\
\text { Madrid }\end{array}$ & 1997 \\
\hline $\begin{array}{c}\text { Jornada de Educación para el desarrollo (Day of } \\
\text { Education for Development) }\end{array}$ & $\begin{array}{l}\text { Education for } \\
\text { development }\end{array}$ & $\begin{array}{c}\text { International Cooperation. } \\
\text { Madrid. }\end{array}$ & 2000 \\
\hline La salud en el mundo (Health in the world) & Human rights & Manos Unidas. Madrid & 2001 \\
\hline $\begin{array}{l}\text { Refugiados y desplazados; huir para sobrevivir } \\
\text { (Refugees and displaced persons; flee to survive) }\end{array}$ & Human rights & Manos Unidas. Madrid & 2002 \\
\hline La vida es antes que la deuda (Life before debt) & $\begin{array}{l}\text { Human rights and } \\
\text { education }\end{array}$ & Manos Unidas. Madrid & 2006 \\
\hline
\end{tabular}

In the words of the teachers, although they considered this aspect fundamental for the education and development of children, "this dimension is addressed specifically from areas of the curriculum" (P1), since "from my point of view it is easier to focus on and analyse the human consequences when we value scientific, historical, fact, etc" (P5). Thus "I think that the student is presented with a more understandable reality" (P17).

The indicators of this study for the group of programmes that were designed to tackle development cooperation gave the following results. See Table 15.

Table 15. Development indicators for programmes on development cooperation

\begin{tabular}{cccccc}
\hline & \multicolumn{5}{c}{ LEVELS } \\
\hline INDICATORS & Absent & Passive & Informative & Formative & Transformative \\
\hline Based on problems of social & 0 & 0 & 2 & 6 & 0 \\
reality & $0 \%$ & $0 \%$ & $25.0 \%$ & $75.0 \%$ & $0 \%$ \\
Promote values and attitudes & 0 & 0 & 1 & 7 & 0 \\
Adapted to curriculum & $0 \%$ & $\%$ & $12.5 \%$ & $87.5 \%$ & $0 \%$ \\
& $25.0 \%$ & $62.5 \%$ & $12.5 \%$ & $0 \%$ & 0 \\
\hline
\end{tabular}




\begin{tabular}{cccccc}
\hline Favour the holistic development & 0 & 1 & 2 & 5 & 0 \\
of the student & $0 \%$ & $11.1 \%$ & $22.2 \%$ & $62.5 \%$ & $0 \%$ \\
Encourage the participation of & 6 & 2 & 0 & 0 & 0 \\
the educational community & $75.0 \%$ & $25.0 \%$ & $0 \%$ & $0 \%$ & $0 \%$ \\
\hline
\end{tabular}

In the case of the programmes designed to address the area of development cooperation, it was observed that they were programmes based on social realities with the aim of generating different opinions and views (75.0\%), that they encouraged the formative development of values and attitudes $(87.5 \%)$, that they included content that was insufficiently adapted to school curricula $(62.5 \%)$, and that they taught with a view to the holistic development of the students $(62.5 \%)$. With regard to encouraging community participation, $75.0 \%$ did not include the community dimension.

\subsubsection{Equality}

The central premise of equality is all schools being able to offer quality education that provides equal opportunities to all children, regardless of their capacities, their physical traits, their sex, race or social class. Education in and for equality is a dynamic concept that evolves in parallel with society. According to the Instituto de la Mujer (Spanish National Women's Institute) (2008) Education for Equality is the current pedagogical approach that responds to the demand for equality as espoused by feminist theory, which proposes a reformulation of the model of transmission of knowledge and ideas in social spaces for training and learning from a gender perspective. In this regard, the proposal from the perspective of inclusion and respect for diversity would contain the basic principle of non-discrimination on grounds of sex (Pérez-Jorge, 2010).

However, despite this fact, programmes that placed special emphasis on this dimension were found. See Table 16.

Table 16. Projects to promote attitude change and values education: Equality

\begin{tabular}{|c|c|c|c|}
\hline Title & Values developed & Author, city and publisher & Year \\
\hline Cómo educar en valores (How to teach values) & Co-education & Paniego, J. A. Barcelona: Graó. & 1999 \\
\hline $\begin{array}{c}\text { Educación y nuevas tecnologías (Education and } \\
\text { new technologies) }\end{array}$ & Equality and education & Manos Unidas. Madrid & 2001 \\
\hline Educar en derechos (Teaching rights) & Rights and equality & Manos Unidas. Madrid & 2007 \\
\hline $\begin{array}{c}\text { Educar a las niñas, educar en futuro (Educating } \\
\text { girls, educating the future) }\end{array}$ & Equality and education & Manos Unidas. Madrid & 2007 \\
\hline DetecAmor & $\begin{array}{l}\text { Educational dialogue. } \\
\text { Equality. }\end{array}$ & IAM. Sevilla & 2014 \\
\hline Proyecto Guaxara 2.0 (Guaxara 2.0 project) & Education for Equality & Asociación Mercedes Machado & 2013 \\
\hline Proyecto Espabilando (Get smart project) & Education for Equality & $\begin{array}{l}\text { Department for Youth Education } \\
\text { and Equality, Tenerife Island } \\
\text { Council }\end{array}$ & 2013 \\
\hline $\begin{array}{l}\text { Red canaria de escuelas por la igualdad (Canary } \\
\text { Islands network of schools for equality) }\end{array}$ & Education for Equality & Canary Islands Government & $\begin{array}{l}2014 \\
2015 \\
\end{array}$ \\
\hline
\end{tabular}

The interviewed teachers said that "at present I do not place particular emphasis on highlighting the idea of respect for gender" (P19), and one of the teachers specified that "today in school girls are not discriminated against because of their condition" (P4). "Girls play and participate in the same activities as boys" (P14), and they also stated that "there are other reasons for which I do see peers making fun of each other, like clothes, dress sense or tastes" (P2).

The indicators of this study for this group of programmes gave the following results. See Table 17.

Table 17. Development indicators for programmes on equality

\begin{tabular}{|c|c|c|c|c|c|}
\hline \multicolumn{6}{|c|}{ LEVELS } \\
\hline INDICATORS & Absent & Passive & Informative & Formative & Transformative \\
\hline \multirow{2}{*}{$\begin{array}{l}\text { Based on problems of social } \\
\text { reality }\end{array}$} & 1 & 1 & 1 & 5 & 0 \\
\hline & $12.5 \%$ & $12.5 \%$ & $12.5 \%$ & $62.5 \%$ & $0 \%$ \\
\hline \multirow{2}{*}{ Promote values and attitudes } & 0 & 1 & 2 & 5 & 0 \\
\hline & $0 \%$ & $12.5 \%$ & $25 \%$ & $62.5 \%$ & $0 \%$ \\
\hline \multirow{2}{*}{ Adapted to curriculum } & 1 & 7 & 0 & 0 & 0 \\
\hline & $12.5 \%$ & $87.5 \%$ & $0 \%$ & $0 \%$ & $0 \%$ \\
\hline Favour the holistic & 0 & 1 & 1 & 6 & 0 \\
\hline development of the student & $0 \%$ & $12.5 \%$ & $12.5 \%$ & $75.0 \%$ & $0 \%$ \\
\hline
\end{tabular}




\begin{tabular}{cccccc}
\hline Encourage the participation of & 7 & 1 & 0 & 0 & 0 \\
the educational community & $87.5 \%$ & $12.5 \%$ & $0 \%$ & $0 \%$ & $0 \%$ \\
\hline
\end{tabular}

In the case of the programmes designed to address equality, it was observed that they were programmes based on social realities with the aim of educating $(62.5 \%)$ to engender equality, that they encouraged the formative development of values and attitudes $(62.5 \%)$, that they included content that was insufficiently adapted to school curricula $(87.5 \%)$, and that they taught with a view to the holistic development of the students $(75.0 \%)$. With regard to encouraging community participation, $87.5 \%$ did not explicitly address the community dimension.

Taking into consideration the dimensions addressed by the programmes, the indicators for each dimension were then compared.

a) Based on problems of social reality (1). Generally a tendency to address this indicator was observed, mainly at the formative level: social reality was presented as something dynamic, changing and interactive that can be changed. The programmes thus invited the students to voice their opinions and assimilate different points of view. See Figure 1.

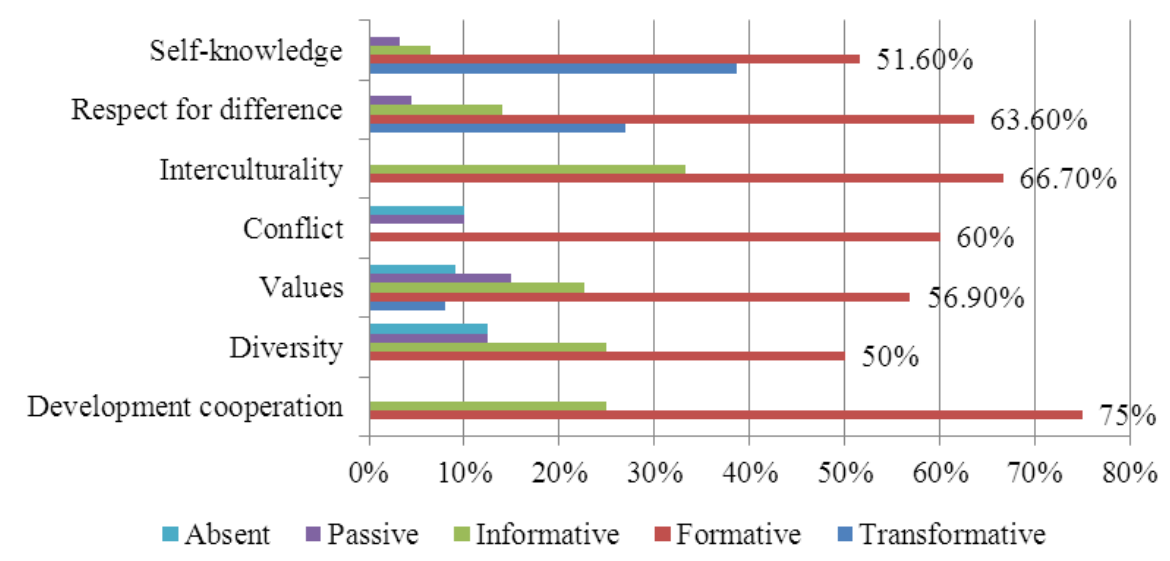

Figure 1. Development levels for indicator 1

b) Promote values and attitudes (2). A formative approach to this indicator was generally observed in the way that values and attitudes were presented as something dynamic. The programmes used reflection and analysis to promote the need to change and adapt values and attitudes as a way of creating a more just and democratic society. See Figure 2.

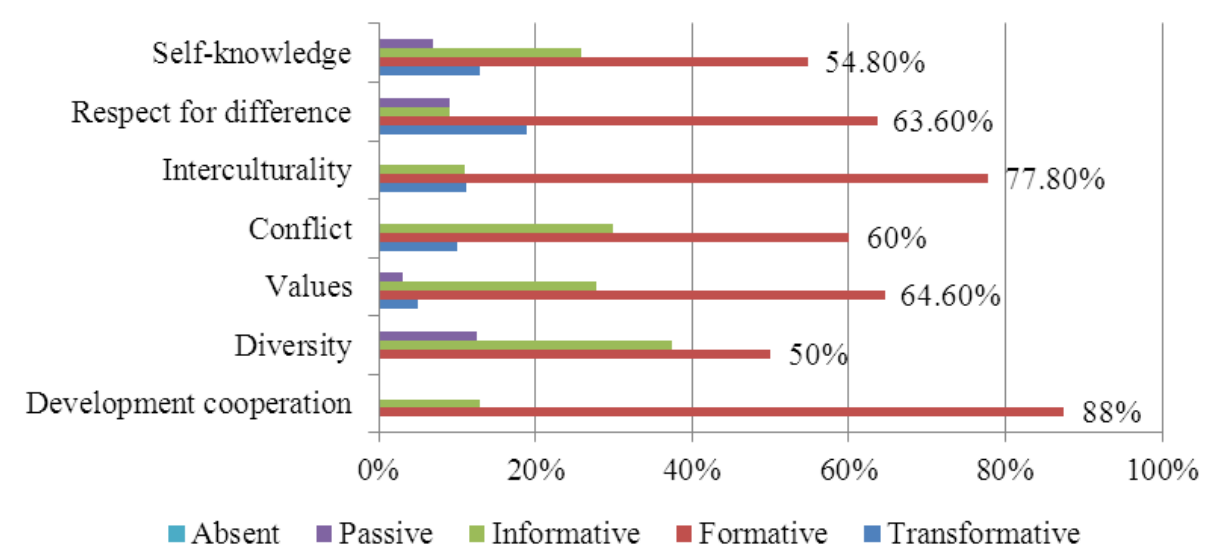

Figure 2. Development levels for indicator 2

c) Adapted to curriculum (3). The programmes designed to work on values in school were created to align with the curriculum design of the educational stages for which they were intended. They were therefore based on a deterministic approach, conditioned by curriculum designs. Their contents are fixed and must be accepted as they are presented; they are unchanging and perpetuated as such. See Figure 3. 


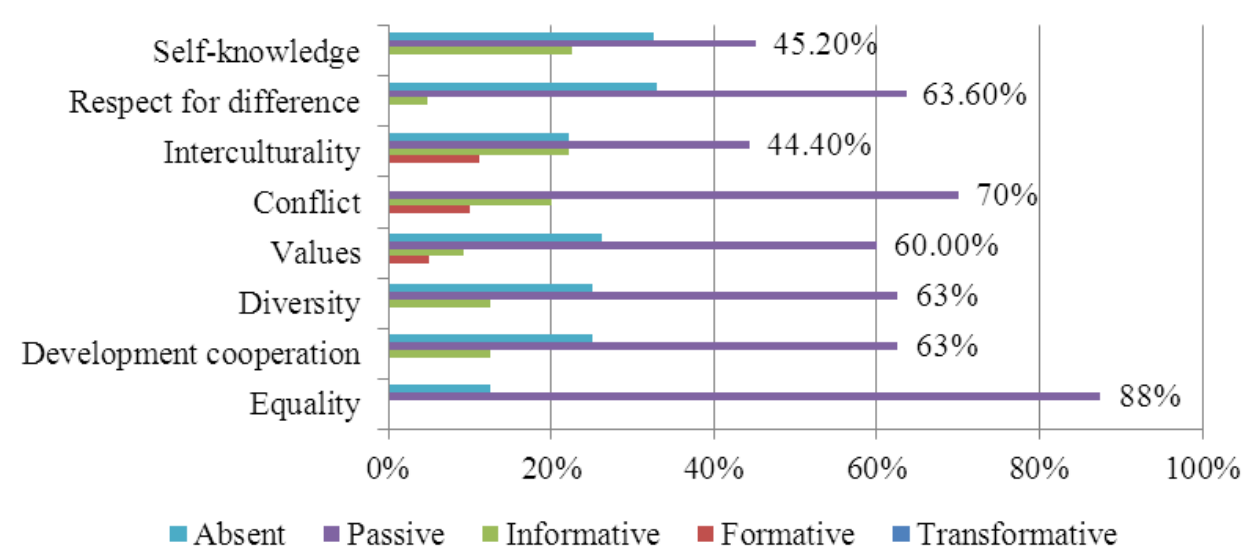

Figure 3. Development levels for indicator 3

d) Favour the holistic development of the student (4). A formative approach to this indicator was generally observed in the way that values and attitudes were presented as something dynamic. The programmes used reflection and analysis to promote the need to change and adapt values and attitudes as a way of creating a more just and democratic society. See Figure 4.

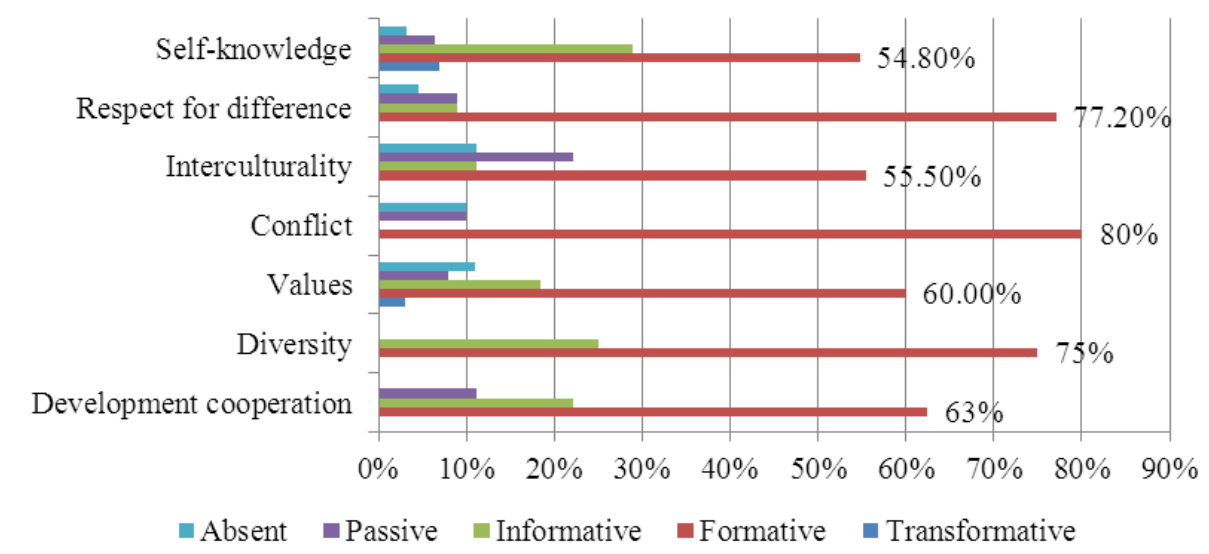

Figure 4. Development levels for indicator 4

e) Encourage the participation of the educational community (5). The participation and involvement of the educational community was virtually non-existent; the programmes left no room for the involvement and integration of the educational community. They were therefore programmes to be developed within individual or collective, but not community-based, models of intervention. See Figure 5.

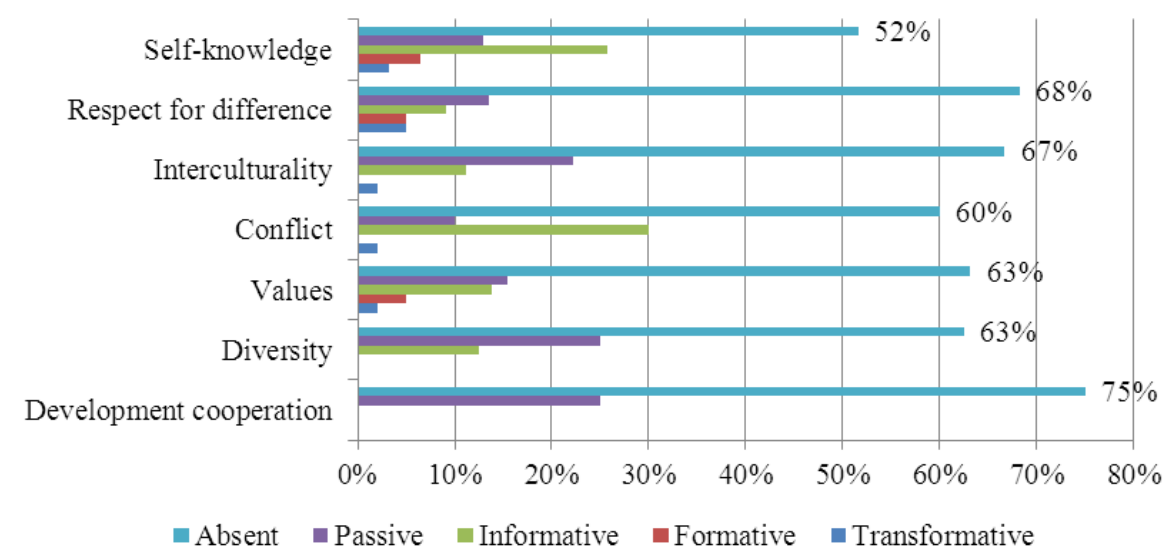

Figure 5. Development levels for indicator 5 


\section{Conclusions}

a) A great variety of areas have been covered by programmes designed to promote attitude change and values education. The areas of knowledge of self and of others, discrimination and human values are those that have been most widely implemented by schools.

b) The evident goals of programmes to encourage attitude change and values education include the development of positive attitudes and values in students. However, despite being designed in line with the curricular structure of primary and secondary school stages, they are not included in school curricula.

c) The teachers saw serious difficulties in implementing values education programmes because they did not match the curricula at those moments that they wanted to develop them in class. One of the fundamental characteristics of the programmes was their cross-cutting nature, despite the fact that they are designed mainly to work with curricula. They were not used often by teachers, who admitted to making little use of them. The programmes were used only very sporadically and on an ad-hoc basis, on special days such as Hunger Day, Peace Day, etc.

d) Recognition of the fact that values education is taught to coincide with specific facts or days, such as Peace Day or International Workers' Day, makes educational intervention isolated and detached from reality. Perhaps it is necessary to rethink how values are taught: analysis of the programmes that have been implemented in Spain for the past 29 years shows that there is an ongoing concern about addressing this issue and that projects organised in parallel to school have continued to emerge to meet a clear need. This may be the result of the deficiencies in values education offered to children by schools.

e) Perhaps the inability of these programmes to identify with school reality and the characteristics of the students have been a significant obstacle to including the contents of these programmes in educational programming. However, we may be witnessing a process of teacher deskilling which has converted them into executors of curricula designed by publishers.

f) An approach to values from the different areas would enable education to be structured and oriented around a range of specific values, which would confer greater meaning on the education itself since it would be brought closer to contexts that are more tangible and real. The crisis of values suffered by today's society, especially by young people, is not down to chance; a change of educational paradigm is becoming increasingly necessary. It is no longer enough to teach knowledge, and the school must educate by promoting moral growth and values education, making educational practice a comprehensive formative action that encompasses knowledge, feeling and action.

g) It is necessary for schools to adopt methodological models that are promoted through these programmes to encourage new ways of sharing and communicating in a suitable, non-hostile climate; a place where people can reflect on ways to feel, think and act.

h) Values education programmes should be part of the personal instruction of students because of their positive influence on learning, and the motivation and stimulation that they engender amongst children.

i) In our search for the path of least resistance, we often forget what we all know: that when we learn, many emotional and relational aspects come into play. Therefore, proposing activities that introduce quality changes in the overall education of children, both in terms of what they have to learn and what it teaches them to be, would guarantee success in their learning, in building their own self-concept as an individual, in the transformation of attitudes towards diversity and towards the other, and in their confidence to deal with the challenges of life from an ethical, egalitarian and transforming position.

j) The formative aspects revealed by the development indicators for the different areas of the analysed programmes denote a somewhat unchanging approach to the values promoted and addressed by these programmes. Their dynamic and interactive approach to reality offers the possibility of showing it from different points of view, allowing children to comment on it. Few of the analysed programmes have presented a transformative vision that invites children to question reality, encouraging a critical vision and engaging them with the need to generate personal and social change.

\section{References}

Arnaiz, P. (2012). Escuelas eficaces e inclusivas: cómo favorecer su desarrollo. Educatio Siglo XX. 30(1), 25-44. file://C:/Users/Usuario/Downloads/149121-557521-1-PB\%20(2).pdf

Ainscow, M., Beresford, J., Harris, A., Hopkins, D. \& West, M. (2001). Crear condiciones para la mejora del trabajo en el aula. Manual para la formación del profesorado. Madrid, España: Narcea. 
Bajaj, M. (2008). Introduction. En M. Bajaj, (Ed.). The Encyclopedia of Peace Education (pp. 1-9). Charlotte: Age Publishing.

Bajaj, M, \& Chiu, B. (2009). Educationfor Sustainable Development as Peace Education. Peace \& Change, $34(4)$, http://s3.amazonaws.com/academia.edu.documents/14785948/bajaj-chiu_final.pdf?AWSAccessKeyId=AKI AIWOWYYGZ2Y53UL3A\&Expires=1496313835\&Signature=anLL1jjdd9jBZOlxZ0g2uDaxMFM\%3D\&r esponse-content-disposition=inline\%3B\%20filename\%3DEducation_for_Sustainable_Development_as.pdf

Bereday, G. (1968). El método comparativo en Pedagogía. Barcelona, España: Herder.

Boqué, M.C., Pañellas, M., Alguacil, M. \& García, L. (2014). La cultura de paz en la educación para la ciudadanía y los derechos humanos en los libros de texto de educación primaria. Perfiles Educativos, 36(146), 80-97. https://doi.org/10.1016/S0185-2698(14)70129-1

Brenes-Castro, A. (2004). An Integral Model of Peace Education. En L. Anita (Ed.), Educating for a Culture of Social and Ecological Peace (pp. 77-98). Nueva York, NY: State University of New York.

Carreras, L., Eijo, P., Estany, A., Gómez, M. T., Guich, R., Mir, V., ... Serrats, M. G. (2006). Cómo educar en valores: materiales, textos, recursos y técnicas. Madrid, España: Narcea.

Carrillo, I. (2007). ¿Es posible educar en valores en familia? Barcelona, España: Graó.

Echeita, G. (2009). Escuelas inclusivas, escuelas en movimiento. En: Macarulla, I. y Saiz, M. (coord.) (2009), Buenas prácticas de escuela inclusiva (pp. 37-55). Barcelona, España: Graó,

Fermán, I., Guzmán, F., Torres, A., Ahumada, C., \& Díaz, F., (2014). Estrategia para modificar conocimientos y actitudes en niños escolares: un programa de educación para la salud. Psicología y Salud, 14(1), 135-142. http://revistas.uv.mx/index.php/psicysalud/article/view/873

Ferrer, F. (2002). La educación comparada actual. Barcelona, España: Ariel.

García-Garrido, J. (1996). Fundamentos de educación comparada. Madrid, España: Dykinson.

González, M. (2015). La Formación del Maestro y la Atención de las Necesidades Educativas Especiales en una $\begin{array}{lllll}\text { Escuela para } & \text { Todos. Tendencias } & \text { Pedagógicas, } & 3, & \text { 85-98. }\end{array}$ file://C:/Users/Usuario/Downloads/1726-3568-1-PB\%20(1).pdf

Grasa, R. (2000). Evolución de la educación para la paz. La centralidad del conflicto para la agenda del siglo XXI", Cuadernos de Pedagogía, 287, 52-56. http://europa.sim.ucm.es/compludoc/AA?articuloId=92756

Gross, J. (2004). Necesidades educativas especiales en educación primaria. Una guía práctica. Madrid: Morata.

Gutmann, A. (2001). La educación democrática: una teoría política de la educación. Barcelona, España: Paidós.

Gispert, C. (2008). Cómo educar además de enseñar. Barcelona, España: Océano.

Harris, I. \& Morrison, M. L. (2003). Peace Education. Jefferson: McFarland \& Co.

Hilker, F. (1964). La Pédagogie comparée. París, France: Institut Pédagogique National.

Ibáñez, R. M. (1993). Los valores, un desafio permanente. Madrid, España: Cincel.

Instituto de la mujer (2008). Guía de Coeducación. Síntesis sobre la Educación para la Igualdad de Oportunidades entre Mujeres y Hombres. Madrid, España: Arias Montano.

Johnson, D. W. \&. Johnson, R. T. (2006). Peace Education for Consensual Peace: The essential role of conflict resolution, Journal of Peace Education, 3(2), 147-174. https://doi.org/10.1080/17400200600874792

Kechikian, A. (2015). Filósofos de la Educación. Educación y Pedagogía, 3(7), 119-128. http://aprendeenlinea.udea.edu.co/revistas/index.php/revistaeyp/article/viewFile/23248/19075

Martín, A. (2011). Fomentar los valores en la educación infantil. Techtraining. http://www.techtraining.es/revista/numeros/PDF/2011/revista_31/125.pdf

Melero, M. (2001). Atención a la diversidad. Revista de educación siglo XXI. Huelva, España: Universidad de Huelva.

Mendoza, J., Romero, M., \& Wetshokonda, J. (2015). Los valores en educación para el desarrollo. Inquietud Empresarial, 14(2), 155-170. file:///C:/Users/Usuario/Downloads/3345-6053-1-PB\%20(5).pdf

Moreno, R. M. (2015). Educación en valores. Programa para su desarrollo en la Educación Secundaria Obligatoria. 
https://revistas.uam.es/tendenciaspedagogicas/article/viewFile/1832/1940

Muñoz, M. L. A. (2014). Diagnóstico e intervención en escuelas desde la política de convivencia escolar y enfoque de derechos humanos/Diagnosis and intervention in schools from living school policy and human rights approach. Actualidades Investigativas en Educación, 14(3), 1-18. file://C:/Users/Usuario/Downloads/16092-31595-1-SM.pdf

Ortega, P., Mínguez, R. \& Gil, R (1994). Educación para la convivencia: la tolerancia en la escuela. Valencia, España: Nau Llibres.

Pepper, S. C. (1958). The sources of value. California: University of California Press.

Pérez-Jorge, D. (2010). Actitudes y concepto de la diversidad humana: Un estudio comparativo en centros educativos de la isla de Tenerife (Doctoral dissertation). Universidad de La Laguna, Canarias, España.

Pérez-Jorge, D. (2010b). El profesor motivador: El profesor que estimula e implica a los alumnos en proyectos para el desarrollo de la competencia cultural y artística. En O. Alegre, O. (Ed.), Capacidades docentes para atender a la diversidad (pp.139-153). Sevilla, España: MAD.

Pérez-Jorge, D. \& Rodríguez, M. C. (2012). Actitudes de los maestros hacia las necesidades especiales de los alumnos. En O. Alegre, (Ed.), Investigación sobre competencias y tecnología para la inclusión y la interculturalidad (pp.180-196). Madrid, España: Arial.

Pérez-Jorge, D. Leal, E, \& Rodríguez M.C. (2012). Voces de los maestros de Educación Especial en un centro Inclusivo: Redefinición de responsabilidades. En O. Alegre, (Ed.), Investigación sobre competencias y tecnología para la inclusión y la interculturalidad (pp.135-146). Madrid, España: Arial.

Pérez-Jorge, D., Alegre, O., Rodríguez-Jiménez, M., Márquez-Domínguez, Y., \& De la Rosa-Hormiga, M. (2016). La Identificación Del Conocimiento Y Actitudes Del Profesorado Hacia Inclusión De Los Alumnos Con Necesidades Educativas Especiales. European Scientific Journal, 12(7), 64-81. http://dx.doi.org/10.19044/esj.2016.v12n7p64

Ponce, F. (2015). Comunidades de aprendizaje: una opción educativa para la población costarricense en desventaja social y en condición de vulnerabilidad/Learning communities: an option for the costa rican socially challenged and under vulnerable condition population. Revista Actualidades Investigativas en Educación, 15(1), 1-16. http://dx.doi.org/10.15517/aie.v15i1.16966

Repetto, M., \& Carvalho, F. (2015). Experiencias de investigación educativa intercultural en la formación de maestros indígenas en Roraima, Brasil. Desacatos. Revista de Antropología Social, 48, 50-65. http://www.scielo.org.mx/scielo.php?script=sci_arttext\&pid=S1405-92742015000200004

Rodríguez, R. A. (2015). El programa de Educación en Valores y su relación con el razonamiento moral, ideología educativa y liderazgo del Centro Docente. Nóesis. Revista de Ciencias Sociales y Humanidades, 22(44), 91-118

Rokeach, M. (1973). The nature of human values. New York, NY: Free Press.

Romero, M. (2014). La transición a la vida adulta de los jóvenes con discapacidad y su inclusión sociolaboral; escuela, familia y trabajo. La Laguna, España: Universidad de La Laguna.

Suárez, A, \& Lorena, L. (2015). Centro de educación para el trabajo y desarrollo humano. Los Encenillos. Bogotá, Colombia: Universidad Católica de Colombia.

Tuvilla, J. (2004). Cultura de paz. Fundamentos y claves educativas. Bilbao: Desclée de Brower.

UNESCO (1995). Towards a Culture of Peace. Unesco's Transdisciplinary Project. http://www3.unesco.org/iycp/

\section{Copyrights}

Copyright for this article is retained by the author(s), with first publication rights granted to the journal.

This is an open-access article distributed under the terms and conditions of the Creative Commons Attribution license (http://creativecommons.org/licenses/by/4.0/). 